\title{
Possibilities of Using Solar Energy in District Cooling Systems in the Mediterranean Region
}

\author{
John Vourdoubas \\ Mediterranean Agronomic Institute of Chania, Chania, Greece \\ Email:vourdoubas@maich.gr
}

How to cite this paper: Vourdoubas, J. (2019) Possibilities of Using Solar Energy in District Cooling Systems in the Mediterranean Region. Open Journal of Energy Efficiency, 8, 21-34.

https://doi.org/10.4236/ojee.2019.82002

Received: March 22, 2019

Accepted: May 31, 2019

Published: June 3, 2019

Copyright $\odot 2019$ by author(s) and Scientific Research Publishing Inc. This work is licensed under the Creative Commons Attribution International License (CC BY 4.0).

http://creativecommons.org/licenses/by/4.0/ (c) (i) Open Access

\begin{abstract}
Use of district heating and cooling systems has many environmental advantages compared to individual heating and cooling. Recent advances in solar energy technologies for heat and power generation have reduced their cost and promoted their use instead of fossil fuels. Solar-PV energy for electricity generation and solar thermal energy for hot water production are broadly used today. Solar energy resources in the Mediterranean region are abundant while space cooling in buildings is required when solar irradiance is high. The possibility of using solar energy for fuelling water chillers providing cold water in district cooling systems in the Mediterranean basin has been investigated. Existing literature and studies concerning the use of district cooling systems globally as well as the energy sources used in them have been examined. Solar-PV energy combined with compression chillers and solar thermal energy combined with thermally driven chillers can be used for cold water production. Their overall efficiencies, converting solar energy to cold water, vary between $22 \%$ and $56 \%$ compared with $45 \%$ for compression chillers using grid electricity. It is concluded that various solar energy technologies could be used with different types of water chillers for fuelling district cooling networks in the future in the Mediterranean region.
\end{abstract}

\section{Keywords}

District Cooling, Efficiency, Mediterranean Region, Solar Energy, Water Chillers

\section{Introduction}

The need to cope with climate change makes necessary the use of more efficient and low carbon emissions energy systems. Buildings utilize large amounts of energy and European buildings consume around $40 \%$ of the total energy con- 
sumption. Use of district heating and cooling (DHC) systems has many economic and environmental advantages compared with individual air-conditioning systems. District heating (DH) is broadly used in central and northern European countries while district cooling (DC) is less used in Europe and worldwide. Combined use of renewable energies with DHC systems is very desirable in order to reduce carbon emissions and to mitigate climate change. Mediterranean countries have huge solar energy resources which are currently used for heat and power generation. However their use in district cooling systems has not been developed commercially so far although the need for space cooling coincides with periods of high solar irradiance.

\section{Literature Survey}

\subsection{District Cooling in Europe and the Mediterranean Region}

Galatoulas et al. [1] have reported on renewable DHC systems in Europe. The authors stated that the $4^{\text {th }}$ generation DHC systems are integrated with renewable energy technologies and cooling from natural water formations. They have also mentioned that solar DC systems have integrated solar thermal systems with absorption chillers while natural water cooling integrates water in low temperatures from natural water sources with DC systems. Papageorgiou et al. [2] have reported on DC technology and its applications. The authors stated that in Greece space cooling is required during the summer and various renewable energies could contribute to it through DC technology. They have also mentioned that DC networks offer an alternative solution to individual cooling systems, resulting in environmental and economic benefits. A report on smart district heating and cooling systems has been produced by the European Energy Research Knowledge Center [3]. The report stated that research is currently carried out concerning the use of solar energy, surplus heat and free cooling from the sea or lakes for cooling generation. It also mentions the need for further financing $\mathrm{R}+\mathrm{D}$ projects in DHC. Mortensen [4] has reported on the impacts of the appropriate legal framework in the promotion of DC. The author stated that even in Nordic countries, buildings require comfort cooling during the summer. Current technology allows the conversion of district heat water to cooling water. Thus countries with large district heating sectors like Denmark, Sweden and Finland could use their existing infrastructure for cooling their buildings. Beccali et al. [5] have investigated the feasibility of using the heat from the co-generation of heat and power (CHP) plants in DHC systems in small Italian islands. The authors have examined the retrofitting of existing power plants to CHP plants and the utilization of the co-produced heat in DHC networks. Performing an analysis in six Italian islands, they concluded that due to the low "linear heat density" observed in small islands, the energy investments resulted were "far from being attractive" except if the investments could be supported with public subsidies. Moia-Pol et al. [6] have reported on solar thermal potential for DHC systems in a tourist area in the Balearic islands, Spain. The authors stated that 
large central solar heating plants in Spain could become an attractive alternative to conventional technologies. These central solar plants could be an excellent complement to DHC networks fuelled with biomass in Palma beach, Spain. Rogowska [7] has reported on DC with a geothermal heat source. The author stated that an absorption cooling system with a LiBr-water cycle using a geothermal heat source could provide cooling in the city of Stargard, Szczecinski, Poland. The absorption cooling system at $500 \mathrm{KW}$ could utilize hot water at $85^{\circ} \mathrm{C}$, achieving a coefficient of performance (COP) of 0.71 . Werner [8] has presented a review on DH and DC in Sweden. The author stated that cold is supplied by using natural cold resources, absorption chillers and mechanical chillers. He also stated that absorption chillers are using heat from waste incineration plants during summer while peak cold loads are often met by cold storage. A report for DC in Europe has been produced during the implementation of the EU funded project ECOHEATCOOL [9]. The report states that the market share of DC in Europe in 2020 could be at $25 \%$ of the total cooling market, corresponding to $165 \mathrm{TWh} /$ year. The main cooling sources are: 1) Natural cooling using cold water from lakes, rivers and sea, 2) Various heat sources including CHP, waste incineration, industrial waste heat, combustible renewables, geothermal and solar energy, and 3) Residual cooling from LNG re-gasification installations. A report on smart cooling for urban Europe (RESCUE) [10] has been published. The report states that cooling in DC networks is usually obtained with a combination of natural cooling, electric chillers and absorption chillers. The expected EER for electric chillers varies between 5 and 14, while in absorption chillers it is between 0.7 and 0.74 for hot water temperature at around $90^{\circ} \mathrm{C}$. A profitability analysis of a 60 MW DC network for 1200 equivalent full load hours and cold water cost at $80 € /$ MWh shows that the a DC network is economically viable. Vourdoubas [11] has reported on the creation of zero carbon emissions hotels in Crete, Greece. The author stated that hotel buildings are energy-intensive buildings while in summer-operating hotels in Crete, Greece, space cooling has a share of around $50 \%$ in their total energy consumption.

\subsection{District Cooling Worldwide}

Jungbauer et al. [12] have compared the efficiency of individual chillers and DC networks. The authors stated that the energy efficiency ratio (EER) in individual installations varies between 0.84 and 2.87. The measured EER values were well below the theoretical efficiencies of these systems indicated by the manufacturers. Domonkovic et al. [13] have reported on the potential of DC in hot and humid climates. The authors stated that if waste heat was efficiently utilized with absorption chillers to generate cold, it could increase energy efficiency. Implementing a case study in Singapore, the authors concluded that DC systems utilizing waste heat and sustainable energies in hot and humid climates have many energy, environmental and economic benefits. Lo et al. [14] have reported on challenges of the DC systems in Hong Kong. The authors stated that DC net- 
works offer significant benefits both in terms of environmental comfort, operational efficiency, energy conservation and superior system reliability. They also mentioned that governmental support is necessary to reduce the risks of their implementation and commercial application. Gang et al. [15] have assessed the performance of district cooling systems coupled with different energy technologies in subtropical areas. The authors mentioned that in urban areas with a high density of buildings, DC is considered as an efficient alternative to supply cooling to a group of buildings. They have investigated the performance of DC combined with thermal storage, with storage in hydro-pumped storage systems and with combined cooling, heat and power (CCHP) generation. They concluded that DC with CCHP is very beneficial, saving around $30 \%$ of the primary energy use. A report on district cooling in China has been produced by Asian Development Bank [16]. The report states that China has a larger market for DC compared to Japan or Europe but smaller than USA. DC can be based on many different energy sources including fossil fuels and renewable energies. According to this report, DC results in an increase of $25 \%-50 \%$ in energy efficiency while, given the right preconditions, it is financially competitive to traditional split air conditioners. Passerini et al. [17] have investigated the optimum control of DC systems. The authors mentioned that different energy sources can be used for cooling generation in DC systems like waste heat and solar energy combined with absorption chillers. Prediction of cooling demand in buildings and the intensity of solar irradiance are difficult. They have developed energy models and a prediction control system in order to improve the design and efficient management of DC networks. IRENA [18] has published a report on renewable energy use in DHC. The report mentions that fossil fuels account for more than $90 \%$ of the fuels used in DHC systems worldwide. DC mostly uses electricity in compression chillers and natural gas in absorption chillers while renewable DC mainly involves free cooling schemes from natural waters. The report also states that when renewable energies requiring large spaces like solar energy are going to be used in DC, they should be carefully integrated into the urban environment. Hui Liu et al. [19] have evaluated a DC system in Kuala Lumpur, Malaysia which has decided to become a low carbon city. The authors have used three parameters to assess the DC system including energy consumption, cost and carbon emissions on an annual basis. Their results indicated that DC systems are expensive in terms of initial investment and operational cost compared to the conventional individual air-conditioners. They also stated that cooling generation combining biogas-fired steam boilers and absorption chillers are the best option. Werner [20] has reported on the use of DH and DC worldwide. The author stated that for cooling production, among other methods, absorption chillers are used, utilizing heat from incineration of waste as well as industrial waste heat. He also stated that due to small temperature differences in DC, the pipes used are wider compared with DH systems of the same capacity. Perez-Mora et al. [21] have reported on solar DH and DC systems. The authors stated that al- 
though DH and solar collectors are well known and used for many years their combination is relatively new. They also mentioned that despite the theoretical advantages of solar DC there are only few studies and existing plants. Most larger solar cooling systems are restricted to a single customer and thus cannot be considered as DC systems.

\subsection{District Cooling and Solar Energy}

Huang et al. [22] have reported that DC technology in China reduces electricity consumption and the peak loads during hot summer days. The authors have evaluated the performance of solar-PV cooling and solar thermal cooling using simulation techniques. Their results indicated that solar cooling with both systems reduces the primary energy consumption by around 30\% compared with electric heat pumps. The payback period for the solar-PV cooling system has been calculated as $6-7$ years while for the solar thermal cooling system it is around 20 years. Marugan-Cruz et al. [23] have reported on DC systems connected to a solar power tower in Spain. The authors stated that during the summer in solar thermal systems with heliostats, there are occasions where the heliostats have to stop focusing on the external receiver because the maximum power that the receiver can withstand has been reached. In these cases the surplus solar heat taken from a second receiver could be utilized in absorption chillers producing cold water. Using simulation techniques they found that the solar cooling produced is able to provide air conditioning in a large number of dwellings. Franchini et al. [24] have evaluated the performance of a solar DC system in typical Middle East climate conditions. The authors have compared two different solar energy technologies: a two-stage Lithium-Bromide absorption chiller driven by parabolic trough collectors and a Lithium-Bromide one-stage absorption chiller with evacuated tube collectors. Using computer simulation, they concluded that the performance of the solar system with parabolic trough collectors was better while its cost was $30 \%$ lower than the solar system with evacuated tube collectors. Perez-Mora et al. [25] have examined optimal solar district cooling harvesting scenarios in Spain. The authors mentioned that in Southern European countries, solar cooling using absorption chillers is a suitable option. They have investigated two different energy technologies for the DHC system located in Majorca, Spain. The two energy systems examined were a solar system and a CHP plant. Their results using simulation techniques indicated that the solar system with a tilt angle of $45^{\circ}$ was superior to the CHP system.

\subsection{Heat Storage in District Cooling Systems}

Benz [26] has reported on thermal energy storage in DC. The author stated that thermal storage in DC systems has many advantages including reduction of peak power demand and energy costs as well as improving the reliability and resilience of the system. Cooling storage includes the use of either phase-change or temperature-change materials. He also mentions that temperature-change mate- 
rials require significantly larger space than phase-change materials. Al Quabeh et al. [27] have reported on chilled water storage in DC systems. The authors stated that the operation of optimal chillers is achieved at around $75 \%$ of their capacity. In order to overcome the high energy consumption under partial cooling loads, they suggested the use of multiple smaller chillers combined with a thermal storage system. Johansson et al. [28] have reported on cold storage in DC systems in Sweden. The authors stated that air-conditioning in Sweden requires large amounts of electricity often during hours of peak power demand. They investigated the use of small-scale cold storage with phase-change materials placed near the customers, concluding that it could be cost-effective. They also reported that peak power shaving with the use of cold storage could be approximately at $10 \%$ $15 \%$ of the peak cooling demand.

The aims of the current work are.

1) The investigation of the possibility of using solar energy technologies for cooling generation in DC systems in the Mediterranean region, and

2) The presentation of the advantages and drawbacks of using solar energy technologies in DC systems.

\section{Demand of District Cooling Systems in the Mediterranean Region}

Cooling demand in the Mediterranean region during the summer is high. In tourist areas, hotel requirements for air-conditioning are currently covered with conventional electrically-driven cooling systems consuming mainly grid electricity. Space cooling in dwellings and service buildings is broadly used while the gradual temperature rise due to climate change is going to increase the building's demand for air-conditioning in the future. Space cooling requirements coincide with high solar irradiance in the Mediterranean region. Since cooling requirements are higher during the midsummer days, the use of electrically-driven individual cooling systems increases the demand of grid electricity and the cost of its generation. However, the use of DC systems, as well as district heating systems, in Mediterranean countries is rather limited compared with their use in northern European countries. Construction and operation of a DC system requires the smooth cooperation of three players including the energy-providing company, the local authorities and the building owners. Local authorities willing to reduce their carbon emissions and to improve their environmental sustainability should promote the use of DC systems in their territories. Regulating framework for DC does not exist in the majority of Mediterranean countries, neither governmental support for the takeoff of the DC industry, which is at an infancy stage. The economic viability of DC systems requires high "linear heat density" which does not exist, apart from in urban areas. In densely populated touristic areas though, the main demand for space cooling is from hotels instead of public buildings. Their economic viability is also ensured when an initial stock of buildings will be connected with the DC network which would 
be easier with public than private buildings. Information about real space cooling demand is rare. The EU annual cold demand has been estimated at $4.2 \mathrm{EJ}$, thereof 2.6 EJ in the residential sector, Werner [20]. The author also states that proportions of service sector buildings using district cooling are about $4 \%$ in USA and $0.7 \%$ in Europe. Perez-Mora et al., [21] has estimated that by 2020 at least $60 \%$ of commercial and public buildings in Europe will be equipped with cooling appliances. Cooling market in EU is estimated at $1220 \mathrm{TWh}$. The share of residential sector is at $710 \mathrm{TWh}$ and of service sector at $512 \mathrm{TWh}$, RESCUE project [10].

\section{Type of Chillers Used for Cooling Generation in DC Systems}

A DC system consists of:

1) A system producing cold water circulated in the distribution network. The temperature of supply water is usually at around $6^{\circ} \mathrm{C}$ while that of return water is at around $16^{\circ} \mathrm{C}$. It should also include a cold water storage tank,

2) A distribution network circulating cold water with supply and return pipes, and

3) A system delivering the cold water in each building including heat exchangers.

The chillers which could be used for cold water production in DC systems include compression chillers, absorption chillers and adsorption chillers. They use either electricity or heat energy at low and medium temperatures which could be produced from fossil fuels or renewable energy sources. Their characteristics are presented in Table 1.

Compression-type chillers have significantly higher COPs than chillers using thermal energy while the COPs of absorption chillers operating in higher temperatures have almost double COPs than the adsorption type. This is due to the fact that the quality of electrical energy is higher than the quality of heat energy. Compression type chillers consuming grid electricity are commonly used in existing DC systems. Heat energy at low and middle temperatures can be produced with various renewable energy technologies including solar energy technologies.

Table 1. Characteristics of various chillers used for cold water production.

\begin{tabular}{cccc}
\hline & Compression chillers & Absorption chillers & Adsorption chillers \\
\hline Compression type & $\begin{array}{c}\text { Mechanical } \\
\text { compression }\end{array}$ & Thermal absorption loop & $\begin{array}{c}\text { Thermal adsorption } \\
\text { of water steam }\end{array}$ \\
Energy source & Electrical energy & Heat energy & Heat energy \\
& & $85^{\circ} \mathrm{C}-150^{\circ} \mathrm{C}$ & $55^{\circ} \mathrm{C}-95^{\circ} \mathrm{C}$ \\
Cooling agent & Chlorinated free & Water with $\mathrm{LiBr}$ or $\mathrm{NH}_{3}$ as & Water with solid as \\
hydrocarbons & absorption agent & adsorption agent \\
Coefficient of & $1.3-1.65$ & $0.6-1.0$ & $0.4-0.6$ \\
\hline
\end{tabular}

Source: Papageorgiou et al., 2006. 
Waste heat from industrial processes or co-produced heat from CHP systems can be used in absorption in adsorption chillers. A schematic flow diagram of a compression chiller powered by a solar-PV system providing cold water in a DC network is presented in Figure 1. In Figure 2 a schematic flow diagram of a thermal chiller fuelled by a solar thermal system providing also cold water is presented.

\section{Solar Energy Use in District Cooling Systems}

Cold water used in DC systems can be produced:

1) From natural waters, lakes, rivers or the sea,

2) From fossil fuels, and

3) From renewable energies including the use of waste heat.

In the Mediterranean region, solar energy is abundant and its technologies for heat and power generation are mature, reliable and cost-effective. Annual solar irradiance in EU Mediterranean countries varies between $1600-2000 \mathrm{KWh} / \mathrm{m}^{2}$ while in Southern Mediterranean countries, it is even higher. Therefore it could be easily used for energy generation in DC systems combined with electric, absorption and adsorption chillers. Solar energy technologies which could be used for electricity and heat generation are presented in Table 2.

The total overall efficiency of the energy generation system using solar energy fuelling the cold water generation system is presented in Table 3.

The overall efficiency concerning the solar energy use to final cold water production with electric or thermal chillers varies between $22.1 \%$ - 56\%. Efficiencies with mature, reliable, well-known and cost-effective solar energy systems are

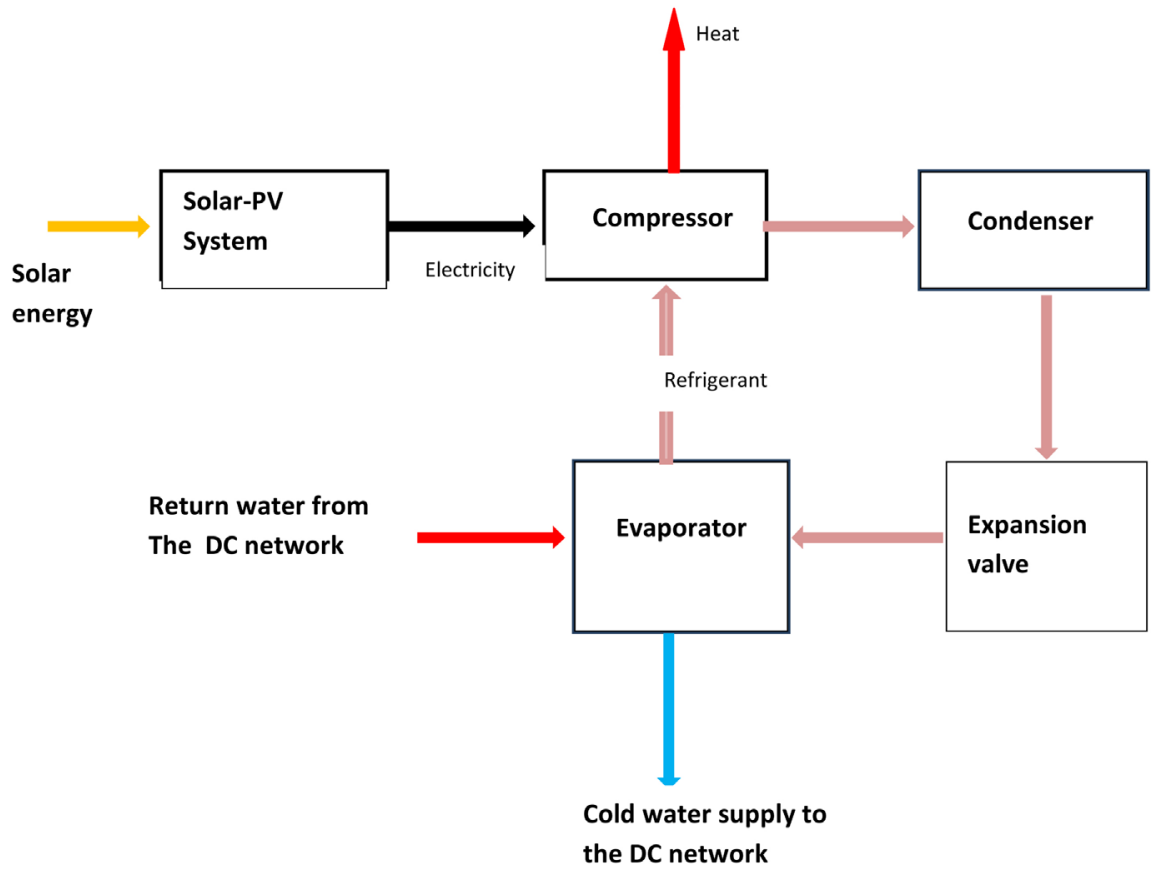

Figure 1. Flow diagram of a compression chiller powered by a solar-PV system and delivering cold water in a DC network. 


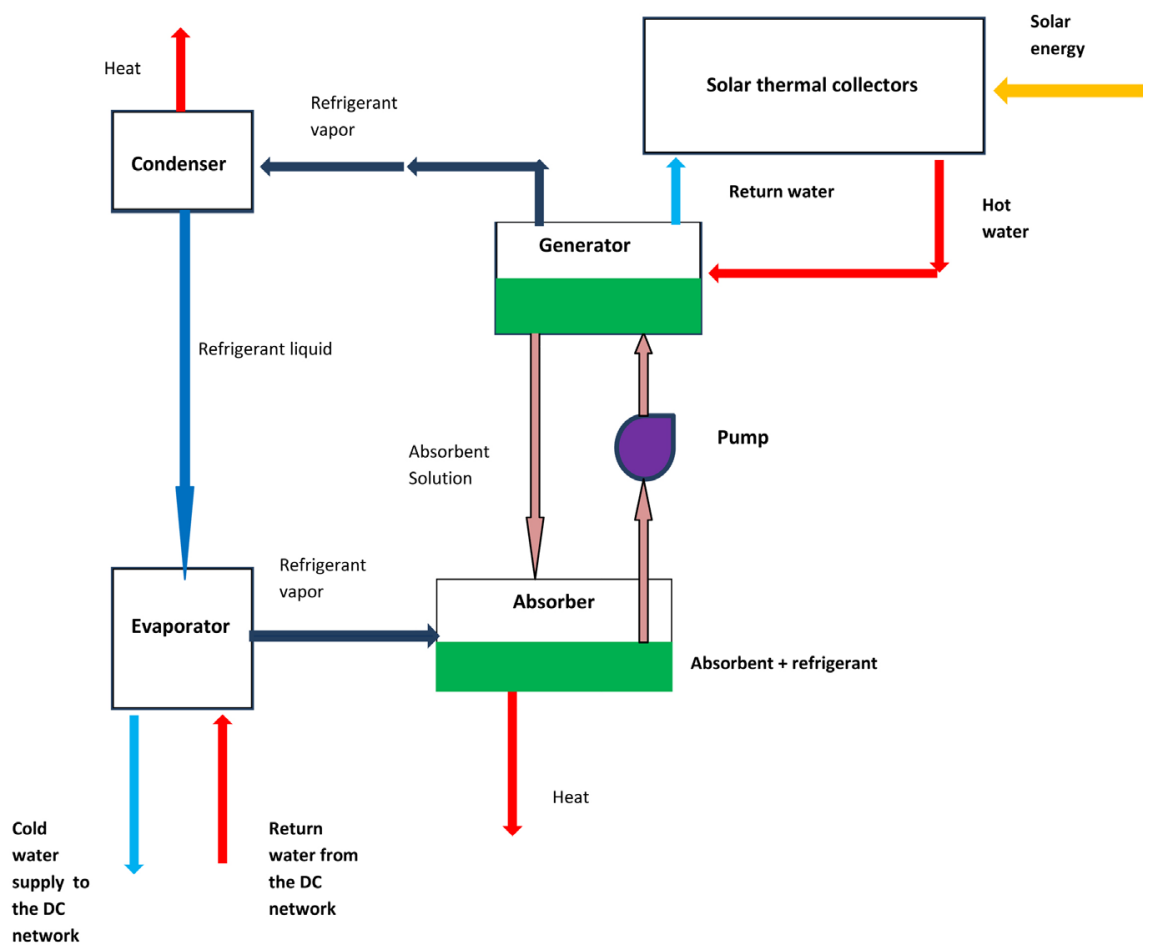

Figure 2. Flow diagram of a thermal chiller coupled with a solar thermal system providing cold water in a DC network.

Table 2. Solar energy technologies which could be used for electricity and heat generation in Mediterranean countries.

\begin{tabular}{|c|c|c|c|c|}
\hline Technology & Solar-PV & $\begin{array}{c}\text { Solar } \\
\text { thermal-flat } \\
\text { plate } \\
\text { collectors }\end{array}$ & $\begin{array}{c}\text { Solar } \\
\text { thermal-evacuated } \\
\text { tubes }\end{array}$ & $\begin{array}{c}\text { Solar } \\
\text { thermal-parabolic } \\
\text { troughs }\end{array}$ \\
\hline $\begin{array}{c}\text { Energy } \\
\text { generated }\end{array}$ & Electricity & $\begin{array}{c}\text { Heat } \\
\left(50^{\circ} \mathrm{C}-60^{\circ} \mathrm{C}\right)\end{array}$ & $\begin{array}{c}\text { Heat } \\
\left(80^{\circ} \mathrm{C}-100^{\circ} \mathrm{C}\right)\end{array}$ & $\begin{array}{c}\text { Heat } \\
\left(100^{\circ} \mathrm{C}-150^{\circ} \mathrm{C}\right)\end{array}$ \\
\hline $\begin{array}{l}\text { Efficiency of the } \\
\text { solar system }\end{array}$ & $15 \%$ & $40 \%-50 \%$ & Higher than 55\% & Higher than $70 \%$ \\
\hline $\begin{array}{l}\text { Possible } \\
\text { integration with }\end{array}$ & $\begin{array}{l}\text { Compression } \\
\text { chiller }\end{array}$ & $\begin{array}{l}\text { Adsorption } \\
\text { chiller }\end{array}$ & Absorption chiller & Absorption chiller \\
\hline $\begin{array}{l}\text { Is the solar } \\
\text { technology } \\
\text { used? }\end{array}$ & Yes, broadly & Yes, broadly & $\begin{array}{l}\text { Yes, in few } \\
\text { applications }\end{array}$ & $\begin{array}{l}\text { Yes, but not } \\
\text { commercially }\end{array}$ \\
\hline $\begin{array}{l}\text { Is the solar } \\
\text { technology } \\
\text { cost-effective? }\end{array}$ & Yes & Yes & $\begin{array}{l}\text { Yes, depending } \\
\text { on the } \\
\text { application }\end{array}$ & $\begin{array}{l}\text { No, depending } \\
\text { on the } \\
\text { application }\end{array}$ \\
\hline
\end{tabular}

around $22 \%$. Overall efficiencies concerning the primary energy use for cold water production with conventional electric chillers are almost double at $45 \%$. Sea water could be used for DC networks since most of the main cities in the Mediterranean region are by the seaside or near to the sea. However the average sea water temperature in the Mediterranean region during the summer months 
Table 3. Total overall efficiency of solar cooling generation used in DC systems compared with conventional space cooling.

\begin{tabular}{cc}
\hline System used & $\begin{array}{c}\text { Efficiency (\%)-primary energy } \\
\text { use to cooling energy }\end{array}$ \\
\hline $\begin{array}{c}\text { Solar-PV combined with compression chiller } \\
\text { Solar thermal-flat plate collectors combined } \\
\text { with Adsorption chiller }\end{array}$ & 22.1 \\
Solar thermal-evacuated tubes combined with \\
$\quad$ Absorption chiller \\
$\begin{array}{l}\text { Solar thermal-parabolic troughs combined } \\
\text { with Absorption chiller }\end{array}$ \\
Heat pumps using grid electricity \\
Compression chillers using grid electricity
\end{tabular}

${ }^{1}$ Efficiency of electricity generation from fossil fuels $=0.3,{ }^{2} \mathrm{COP}$ of heat pumps $=3.5$. Source: Own estimations.

is approximately at $14^{\circ} \mathrm{C}-20^{\circ} \mathrm{C}$ which is not appropriate for use in DC networks. Use of various solar energy systems in DC networks requires large space availability. Therefore large surfaces should be available near the water chillers in order to install the solar-thermal or solar-PV systems.

\section{Advantages and Drawbacks of District Cooling Systems Using Solar Energy in Mediterranean Countries}

Although commercial DC systems using solar energy in Mediterranean countries have not been developed to a large extent so far, technological advances and the necessity to use more efficient sustainable energy systems could trigger their development soon. The advantages and drawbacks of these systems are presented in Table 4.

\section{Discussion}

There are currently no successful commercial DC systems using solar thermal energy and thermal chillers in Mediterranean countries although the conditions for their use are favorable. Existing studies verifying the economic viability of district cooling systems in the region are rather limited while these sustainable energy systems have not been prioritized by the local and regional authorities. Buildings in Mediterranean countries demand heating only for a few months in the winter and cooling only for a few months in the summer. Therefore appropriate systems for both heating and cooling would be preferable. Solar energy systems using flat plate collectors are well proven and broadly used but they achieve low hot water temperatures, resulting in low efficiencies in thermal water chillers. Solar energy systems achieving higher hot water temperatures and higher efficiencies in thermally-driven chillers like those using evacuated tubes and parabolic troughs or discs are not broadly used. Solar energy could also be used combined with other heating fuels in hybrid energy systems, producing the 
Table 4. Advantages and drawbacks of district cooling systems using solar energy in Mediterranean countries.

\begin{tabular}{|c|c|}
\hline Advantages & Drawbacks \\
\hline $\begin{array}{l}\text { Increase of overall energy efficiency } \\
\text { in space cooling in buildings }\end{array}$ & $\begin{array}{l}\text { Lack of existing successful DC systems using } \\
\text { solar energy in the Mediterranean region }\end{array}$ \\
\hline $\begin{array}{c}\text { Decrease of carbon emissions due to } \\
\text { energy use in buildings }\end{array}$ & $\begin{array}{c}\text { Lack of regulating framework promoting DC } \\
\text { in Mediterranean countries }\end{array}$ \\
\hline $\begin{array}{l}\text { Solar energy resources in the } \\
\text { Mediterranean region are high }\end{array}$ & $\begin{array}{l}\text { High space availability is required for } \\
\text { the installation of solar energy systems }\end{array}$ \\
\hline $\begin{array}{l}\text { High building density exists in various } \\
\text { tourism-dominated communities }\end{array}$ & $\begin{array}{l}\text { The experience in solar energy systems using } \\
\text { evacuated tubes or parabolic troughs which } \\
\text { result in high efficiencies is limited. Use of } \\
\text { solar thermal energy with flat plate collectors } \\
\text { are mature and well-known systems which } \\
\text { result in low total energy efficiencies }\end{array}$ \\
\hline $\begin{array}{l}\text { DC and solar energy technologies are } \\
\text { reliable, mature and well proven }\end{array}$ & $\begin{array}{l}\text { Local and regional authorities in Med } \\
\text { countries have no experience in DC systems }\end{array}$ \\
\hline $\begin{array}{c}\text { High solar energy availability exists } \\
\text { when space cooling is needed in } \\
\text { Mediterranean region }\end{array}$ & DC systems require a high initial investment \\
\hline $\begin{array}{c}\text { Individual air conditioning systems are not } \\
\text { needed in buildings using DC energy }\end{array}$ & $\begin{array}{c}\text { Storage of chilled water is needed in order to } \\
\text { be used when the solar irradiance is low }\end{array}$ \\
\hline
\end{tabular}

heat required in thermal chillers. Cold storage is desirable in order to cover the peak cooling loads and to improve the efficiency of the chillers. In the case of using solar energy, cold storage is necessary for providing cooling when solar irradiance is low and during the night. The network pipes carrying the cold water in the Mediterranean region require thermal insulation since the temperature differences are high and the thermal losses will also be high if the insulation of the pipes is not provided. The lack of a favorable legal framework and supporting financial mechanisms hinder the development of DC systems in the region. Since solar-PV technology is currently mature and cost-effective it could be combined with compression chillers replacing grid electricity use and reducing or zeroing the carbon emissions during the operation of the DC system. In this case the problem of finding large spaces for the installation of the solar energy systems either in urban areas or in dense touristic areas should be solved.

\section{Conclusion}

DC systems consist of an efficient and sustainable energy technology providing air-conditioning in buildings, resulting in the mitigation of climate change. Currently the use of DC systems in Mediterranean countries is limited. Demand for space cooling in buildings coincides with high solar irradiance in this region. Therefore it is desirable to utilize a local renewable energy resource like solar energy for cold water production since carbon emissions will be minimized. Various electrically- or thermally-driven chillers can be used for cold water 
production. Solar-PV electricity can be used for fuelling compression chillers. Solar thermal energy produced with various systems can also be used for fuelling thermally-driven chillers. Overall energy efficiency of solar cooling generation varies at around $22 \%$ - 56\% depending on the solar system used. Support from the local authorities regarding the establishment of a regulating framework and offering financial subsidies is probably required for the development of DC systems in the region. In some Mediterranean urban areas and in tourism-dominated communities, the "linear cooling density" is satisfactory to justify the development of DC systems. Further feasibility studies and research are needed in order to evaluate the investment cost and the profitability of DC systems in EU and non-EU Mediterranean countries. Detailed studies should also be implemented concerning the use of solar energy in hybrid energy systems utilizing additional fuels, including natural gas for providing heat in thermally-driven chillers in DC networks.

\section{Conflicts of Interest}

The author declares no conflicts of interest regarding the publication of this paper.

\section{References}

[1] Galatoulas, F., Frere, M. and Ioakimidis, C.S. (2018) An Overview of Renewable Smart District Heating and Cooling Applications with Thermal Storage in Europe. Proceedings of the 7 th International Conference on Smart Cities and Green ICT Systems, Funchal, 16-18 March 2018, 311-319. https://doi.org/10.5220/0006785703110319

[2] Parageorgiou, K.P., Anastaselos, D. and Paradopoulos, A.M. (2006) District Cooling, a Technology with Great Potential of Application. International Workshop on Energy Performance and Environmental Quality of Buildings, Milos Island, July 2006, 1-6.

[3] SETIS, Energy Research Knowledge Center (2014) Thematic Research Summary, Smart District Heating and Cooling. https://setis.ec.europa.eu/energy-research/sites/default/files/library/ERKC_\%20TRS _Smart_District_HC.pdf

[4] Mortensen, B.O.G. (2014) Legal Framework as a Core Element of District Cooling Success-The Case of Denmark. Journal of Power and Energy Engineering, 2, 41-48. https://doi.org/10.4236/jpee.2014.29007

[5] Beccali, M., Giulla, G., Di Pietra, B., Galatioto, A., Leone, G. and Piacentino, A. (2017) Assessing the Feasibility of Co-Generation Retrofit and District Heating/ Cooling Networks in Small Italian Islands. Energy, 141, 2572-2586. https://doi.org/10.1016/j.energy.2017.07.011

[6] Moia-Pol, A., Martinez-Moll, V., Pujol Nadal, R. and Rigo Serra, J.M. (2014) Solar Thermal Potential for Collective Systems in Palma Beach (Balearic Island's). Energy Procedia, 48, 1118-1123. https://doi.org/10.1016/j.egypro.2014.02.126

[7] Rogowska, A. (2003) District Cooling by a Geothermal Heat Source. The United Nations University, Geothermal Training Program, Reykjavik, Report 19, 465-487.

[8] Werner, S. (2017) District Heating and Cooling in Sweden. Energy, 126, 419-429. 
https://doi.org/10.1016/j.energy.2017.03.052

[9] (2006) Possibilities with More District Cooling in Europe, ECOHEATCOOL, Final Report. Intelligent Energy Europe Program.

https://ec.europa.eu/energy/intelligent/projects/sites/iee-projects/files/projects/docu ments/ecoheatcool_more_district_cooling_in_europe.pdf

[10] District Cooling and the Customer's Alternative Cost, Work Package 2, Rescue Project (2012-2015). http://www.rescue-project.eu

[11] Vourdoubas, J. (2015) Creation of Hotels with Zero $\mathrm{CO}_{2}$ Emissions Due to Energy Use: A Case Study in Crete, Greece. Journal of Energy and Power Sources, 2, 301-307. https://doi.org/10.15640/jea.v3n2a9

[12] Jungbauer, J., Serrano Garcia, D., Wallisch, A., Dalin, P., Terouanne, D. and Wirgentins, N. (2011) Measurements of Individual Chiller Systems Compared to District Cooling Solutions. ECEEE 2011 Summer Study, Energy Efficiency First, The Foundation of a Low Carbon Society, 1423-1430.

[13] Dominkovic, D.F., Bin Abdul Rashid, K.A., Romagnoli, A., Pedersen, A.S. and Leong, K.C. (2017) Potential of District Cooling in Hot and Humid Climates. Applied Energy, 208, 49-61. https://doi.org/10.1016/j.apenergy.2017.09.052

[14] Lo, I.A., Lau, I.B. and Cheng, V. (2013) Challenges of District Cooling Systems Implementation in Hong Kong. Hong Kong Regional Conference "Urban Density and Sustainability", Hong Kong, 12-13 September 2013.

[15] Gang, W., Wang, S., Xiao, F. and Gao, D. (2015) Performance Assessment of District Cooling System Coupled with Different Energy Technologies in Subtropical Areas. Energy Procedia, 75, 1235-1241. https://doi.org/10.1016/j.egypro.2015.07.166

[16] Asian Development Bank (2017) District Cooling in the People's Republic of China-Status and Development Potential. https://doi.org/10.22617/RPT168582-2

[17] Passerini, F., Sterling, R., Keane, M., Klobut, K. and Costa, A. (2017) Energy Efficiency Facets: Innovative District Cooling Systems. Entrepreneurship and Sustainability Issues, 4, 310-318. https://doi.org/10.9770/jesi.2017.4.3S(6)

[18] International Renewable Energy Agency (2017) Renewable Energy in District Heating and Cooling.

https://www.irena.org/publications/2017/Mar/Renewable-energy-in-district-heating -and-cooling

[19] Hashim, H., Lim, J.S., Muis, Z.A., Liew, P.Y., Ho, W.S., et al. (2017) Technical and Economic Evaluation of District Cooling System as Low Carbon Alternative in Kuala Lumpur City. Chemical Engineering Transactions, 56, 529-534.

[20] Werner, S. (2017) International Review of District Heating and Cooling. Energy, 137, 617-631. https://doi.org/10.1016/j.energy.2017.04.045

[21] Perez-Mora, N., Bave, F., Andersen, M., Bales, Ch., Lennermo, G., Nielsen, Ch., Furbo, S. and Martinez-Moll, V. (2017) Solar District Heating and Cooling: A Review. International Journal of Energy Research, 42, 1419-1441.

https://doi.org/10.1002/er.3888

[22] Huang, L. and Zheng, R. (2018) Energy and Economic Performance of Solar Cooling Systems in the Hot-Summer and Cold Winter-Zone. Buildings, 8, 37. https://doi.org/10.3390/buildings8030037

[23] Marugan-Cruz, C., Sanchez-Delgado, S., Rodriguez-Sanchez, M.R., Venegas, M. and Santana, D. (2015) District Cooling Network Connected to a Solar Power Tower. Applied Thermal Engineering, 79, 174-183. https://doi.org/10.1016/j.applthermaleng.2015.01.032 
[24] Franchini, G., Brumana, G. and Perdichizzi, A. (2018) Performance Prediction of a Solar District Cooling System in Riyadh, Saudi Arabia-A Case Study. Energy Conversion and Management, 166, 372-384.

https://doi.org/10.1016/j.enconman.2018.04.048

[25] Perez-Mora, N., Lazzeroni, P., Canals, V., Repetto, M. and Martinez-Moll, V. (2016) Optimal Solar District Cooling Harvesting Scenarios. Conference EuroSun 2016, Palma de Mallorca, 11-14 October 2016. https://doi.org/10.18086/eurosun.2016.05.07

[26] Benz, S. (2016) Thermal Storage for District Cooling. Symposium on Thermal Energy Storage, Operational Experience and Economic Value, Austin, 8-12 February 2016.

https://www.districtenergy.org/HigherLogic/System/DownloadDocumentFile.ashx? DocumentFileKey=24d25099-db95-85fc-3c80-21802ec05a8f

[27] Al Quabeh, H., Saab, R. and Ali, M.I.H. (2019) Chilled Water Storage Feasibility with District Cooling Chiller in Tropical Environment. Journal of Sustainable Development of Energy, Water and Environment Systems. https://doi.org/10.13044/j.sdewes.d7.0259

[28] Johansson, C., Martin, V., He, B. and Setterwall, F. Distributed High Capacity Cold Storage in District Cooling Systems.

https://pdfs.semanticscholar.org/f875/497b56c3c5683b7e81fff096d84a40c96cc1.pdf 